\title{
Teachers: Having a voice and being heard? Evidence from two private schools in Nepal
}

\author{
Chandra Lal Sharma Poudyal
}

\begin{abstract}
Profit-oriented private schools in Nepal are usually owned and managed by those people who put money into schools. In such private schools, owners are usually the principals, and schools' administration is run according to the decisions of owners instead the kinds of rules and regulations applicable to state schools. These private schools exclude most of the stakeholders (parents, teachers and other non-owner staff) from the decision making process. However, with political changes in the country overthrowing an absolute monarchy for a constitutional monarchy in 1990, and then to a republic in 2008, scenarios within these schools seem to have changed.
\end{abstract}

This research is an attempt to explore the realities of private school life from the viewpoint of teachers, administrators (middle level managers) and principals in the changed political context of Nepal. It has used semi-structured interviews from two schools selected as the prime source of data for the case study. In addition to semi-structured interviews, field notes and documentary sources form supplementary sources of data. This study suggests that the non-separation of management and ownership in both private schools created a concentration of power in the schools' owners. However, with the political change in the country and subsequent unionisation of private schoolteachers and other non-owner staff, they have now started perceiving themselves as having a voice, even when their voice is not being heard. School owners have developed different strategies to deal with the changing context within and outside the schools, in order to maintain power, control and profits.

The schools' owners, operating a hierarchy of power similar to monarchs, exercised power over the non-owner staff, including teachers working in different levels of the school, to extract their time and labour. However, since the advent of the republic and subsequent unionisation of private schoolteachers, power relations within schools began to shift. Non-owner staff (including teachers) of the two private schools in my study, by deriving power through networks and alliances, started collective bargaining on their rights and privileges. This brought about a scenario of continuous tension between the schools' owners and non-owner staff. Arising from the study, I detected differences in the modes of power relations existing between primary level teachers and schools' owners, and secondary level teachers and schools' owners. One of the reasons behind such differences is linked to the market orientation of private schools. It is apparent that such schools focus on their students' performance in the standardised national level tests, the School Leaving Certificate (SLC) examination, using these results to compete with other schools. Since the secondary level students are the ones sitting in the SLC examination, school owner attitudes towards secondary level teachers was found to be quite different from their attitudes to primary level teachers.

Wilf Malcolm Institute of Educational Research, Faculty of Education, University of Waikato, Hamilton, New Zealand ISSN: 2382-0373

Permanent Research Commons link to full thesis: http://hdl.handle.net/10289/10584 (pp. 119-120) 
This study adds to the sparse literature on the perceptions and experiences of teachers, administrators and owner/principals of private schools in Nepal in the altered political context of the country, even though the sample size is small. It also has enhanced our understanding of school organisations within the private school contexts and teachers' professionalism in the changed political context. It furthers our understanding of how the wider political environment of the country is reflected within these schools' organisation and distribution of power. Finally, I am expecting that my study will support academic debates about teachers' professionalism in private schools of Nepal. 